\title{
Intrepretative Phenomenological Analysis: Perception of Health Risk of Smoking and Smoking Cessation Among Pharmacy Students
}

\author{
Amelia Lorensia and Anggara Martha Pratama \\ Faculty of Pharmacy \\ Universitas Surabaya
}

\author{
Ananta Yudiarso \\ Faculty of Psychology \\ Universitas Surabaya
}

\begin{abstract}
Smokers can experience addiction that impedes their efforts to quit smoking. Smokers' perception and view of quitting smoking are worthy input for health practitioners to promote smoking cessation programs. The purpose of this study was to explore the perception of health risks of smoking and smoking cessation. The method was based on the phenomenological perspective using interpretative phenomenological analysis involving pharmacy students. The study was conducted over two years using snowball-purposive sampling. Participants were smokers who started smoking when they were 18 years old and had previously tried to quit smoking. Results showed that participants started smoking because of curiosity and influences from environments. All participants understood the risks of smoking, and had tried to quit smoking because smoking affected their health and economical status. Therefore, health programs need to focus on smokers' behavior and barriers to quitting smoking since those who have good knowledge on the risks of smoking can experience difficulty in quitting smoking.
\end{abstract}

Keywords: perception, smoking cessation, pharmacy students

Perokok dapat mengalami adiksi sehingga menyulitkan usaha berhenti merokok. Persepsi dan pandangan seorang perokok terhadap pengalaman berhenti merokok, menjadi masukan bagi tenaga kesehatan dalam meningkatkan program berhenti merokok. Tujuan penelitian adalah menggali persepsi kesadaran kesehatan dalam berhenti merokok. Metode penelitian ini berdasarkan perspektif fenomenologis dengan interpretatif fenomenologis analisis pada mahasiswa fakultas farmasi yang dilakukan selama dua tahun dengan menggunakan snowball-purposive sampling. Partisipan adalah perokok sejak berusia 18 tahun dan pernah mencoba berhenti merokok. Hasil penelitian menunjukkan bahwa awal mula partisipan merokok dipengaruhi rasa penasaran dan pengaruh lingkungan. Semua responden mengetahui bahaya akibat merokok, dan telah mencoba berhenti merokok karena rokok telah memengaruhi faktor kesehatan dan financial mereka. Oleh karena itu, program kesehatan perlu difokuskan terhadap perilaku dan hambatan seorang perokok, karena mereka yang memiliki pengetahuan yang baik terhadap bahaya rokok juga mengalami kesulitan berhenti merokok.

Kata kunci: persepsi, berhenti merokok, mahasiswa farmasi

Cigarettes are a serious threat to the health of people around the world that can lead to death. Indonesia is the fifth largest producer of tobacco as well as the largest producer and exporter of cigarettes in the world. Further, Indonesia is the third largest cigarette consumers in the world (GATS, 2012). Cigarettes and tobacco smoke contain dangerous chemical substances that are harmful to the body, causing the body susceptible to diseases that could risk the health of smo-

Correspondence concerning this article should be addressed to Amelia Lorensia, Departement of Clinical-Community Pharmacy Faculty of Pharmacy Universitas Surabaya Jalan Raya Kalirungkut Surabaya 60293. E-mail: amelia.lorensia @ gmail.com kers and other people (Fawzani \& Triratnawati, 2005; Hutapea, 2013). The most effective or healthiest way is quitting smoking. However, the habit of smoking can create problems to those who are addicted to cigarettes (Neal \& Benowitz, 2008).

Nicotine is the main substance in cigarettes that causes addiction. Nicotine stimulates acetylcholine receptors on neurons that contain dopamine. This stimulation causes an increase of dopamine in the central of brain reward system. The peak level of nicotine and activation of brain reward system are followed by a gradual decrease level of nicotine to the point of withdrawal that can only be removed by smo- 
king. Nicotine causes the feeling of pleasure that leads to addiction. When smokers attempt to reduce or quit smoking, they show the symptoms of anxiety and restlessness. The longer nicotine stays in the body, the stronger smoking behavior, which makes smokers experience difficulties in quitting smoking (Neal \& Benowitz, 2008; Sadikin \& Lousia, 2011; Mansvelder \& McGehee, 2002; Berrendero, Robledoa, Trigoa, Martín-Garcíaa, \& Maldonadoa, 2010).

Efforts to quit smoking can be hindered by factors, such as smokers' lack of confidence and low self-esteem that lead to depression, which is the significant factor that causes a failure in smoking cessation (Guillon, Crocq, \& Bailey, 2007). Thus, it is important that health practitioners work in collaboration with other health professionals to assist people who have a desire to quit smoking and to provide counseling on the risks of smoking (BPOM, 2005; BPOM, 2007).

The guideline of smoking cessation suggests that health practitioners should give more attention to the smoking status of each patient and hold a smoking cessation program at least once a year (Sinclair, Bond, $\&$ Stead, 2008). Health practitioners needs to have knowledge not only about the role of smoking as the main risk factor of heart disease, but also about the impact of smoking on other pathophysiology, the interaction between nicotine and other medicines, and the pathophysiology of nicotine addiction, including the withdrawal symptom of nicotine so as to provide an accurate and satisfying information to active smokers. Health practitioners should also understand that smoking is not only related to nicotine addiction, but also a matter of habit (Sadikin \& Lousia, 2011). Research by Twyman, Bonevski, Paul, and Bryant (2014) indicated the barriers experienced by participants to quit smoking based on the phenomenological perspective, or from the perspectives of participants in order to reconstruct the service of primary health care (Veny et al., 2011). Based on the research background above, the aim of this study was to explore factors that initially influence participants to smoke, attempts made by participants to quit smoking, the impact of smoking, and participants' perception on smoking cessation.

\section{Methods}

\section{Research Type and Variables}

This study was based on the phenomenological per- spective using interpretative phenomenological analysis (IPA) to explore and obtain a complete picture of life context of smokers in which the smoking cessation occurred. Based on the government regulation number 81 in 1999 (PP No. 81 tahun 1999), cigarettes are the result of processed tobacco in wrap, including cigars or other forms produced by plants, such as Nicotina tabacum, Nicotina rustiuca, and other species, or synthesis containing nicotine and tar with or without additives. Variables in this study were knowledge, perception, and risks. Knowledge was defined as participants' knowledge about smoking cessation, including definitions, benefits, and understanding of smoking cessation in relation to health, economy, and environment. Perception was referred to the opinion of participants about smoking cessation, including benefits felt and difficulties encountered based on their experiences, impressions, and knowledge, as well as the known risks to self and surroundings in relation to smoking cessation based on their experiences, impressions, and knowledge.

\section{Population and Sample}

Population in this study was pharmacy students at the University of XXX. Sample (participants) was active smokers aged 18 years and over, undergraduate students at the Faculty of Pharmacy at the University of XXX. This study included pharmacy students as they represented individuals with good educational backgrounds who understood the risks of smoking to health. We included those who were 18 years and over, as people at this age range were most likely to smoke (GATS, 2012; Health United States; 2010), and those who had previously tried but failed to quit smoking.

Sampling techniques were snowball sampling and purposive sampling, the prospective participants were encountered in several public places on campus where students commonly smoked. The smokers who were participants in this study were asked to introduce the authors to their friends/relatives who were then approached as prospective participants.

\section{Data Collection and Analysis}

The process of data collection involved preparation of equipment, such as interview guidelines, stationery, and a recorder. Data were collected using in-depth interviews until data reach saturation. 
Data analysis is a technique in qualitative research that is conducted after data have been collected. It starts with open coding, axial coding and then selective coding. At the stage of open coding, verbatim transcription was conducted with the purpose of describing the interview process and reflecting the results of interview (self-reflection).

\section{Results}

Based on in-depth interviews conducted with 15 participants regarding their perception on smoking cessation programs, it was found that across participants, the answers were relatively the same. This study had been conducted for almost two years (from March 2014 to July 2016). The focus of the study was on exploring factors that initially influenced participants to smoke, attempts they made to quit smoking, the impact of smoking, and participants' perception on smoking cessation. After conducting interviews with participants, the authors transcribed the interviews, summarized them in a table and used parts of the interviews to further understand the themes of the interview related to the topic of study.

\section{Initial Factors Influencing Participants to Smoke}

External factors (environment). Other people's influences, such as friends or family members.

"At first, it's only experimenting because of friends, Mas, then I'm starting to get addicted."

"Yes, from the very start, my friend is smoking, Mas."

"Just experimenting, Mas, I only follow my friends who are used to smoking."

"At first, I went along with my friends, Mas, experimenting with my friend's cigarette, and then I become addicted, Mas."

"I think it's a matter of relationships, Mas, because my friends are smoking, I'm following them and smoke, Mas."

"In the beginning?? Hmmm my family is all smokers, that is why I tried to smoke, and by coincidence my friends also like to smoke, so I began to smoke as well, Mas."

"I started to smoke when I was in the third grade of elementary school, at that time my uncle took me to a stall and tried ARDATH ${ }^{\circledR}$, ARDATH $^{\circledR}$ cigarette tasted sweet, after coming back from the stall, at home we have a store, I took a cigarette from the store and began to smoke, at that time I tried ARDATH ${ }^{\circledR}$ cigarette as well, I quitted smoking some time during the third grade, but I started to smoke again when I was in the junior high school."

Internal factors (self). Smoking among adolescents could be related to a psychosocial crisis as a part of adolescent developmental stage, in particular when adolescents search for their identity. However, efforts to form identity do not always run well in accordance to the society's expectations. Several adolescents smoked for compensation; that is, as a way to promote their self-confidence during identity formation process.

"Yes, at first I just wanted to try, it's truly a personal desire, Mas."

"No worries, Mas, at first I'd like to try a bit, I found that it tasted good and finally, I've got addicted, Mas, all started from trial and error, Mas."

\section{Participants' Knowledge About the Impact of Smoking.}

The most obvious consequence of smoking as mentioned by all participants was health problems, particularly respiratory problems that might cause cancer and death. Participants knew about the risks of smoking; that is, disadvantages of smoking to finances and health.

"Oh, I often experience that, Mas, shortness of breath, Mas, I had difficulties to breathe for 4-5 months, Mas."

"I don't have any sickness, Mas, but when I woke up in the morning, Mas, I felt my chest was tight, Mas."

"I know, Mas, it can cause cancer, Mas."

"Yes, Mas, I know, Mas, lung cancer and others, Mas."

"Yes, Mas, I know what are the risks of smoking, Mas, shortly, it can lead to death, Mas."

"I know, Mas, the dangers of smoking, Mas, it can cause lung diseases, and at the end, it can lead to death, Mas."

\section{Participants' Perception on the Risks of Smoking}

The participants' perceptions on the risks due to smoking habit were as follows:

\section{Health problems.}

"In the past, every time I woke up in the morning, I felt my chest was painful, really hurt, Mas, feeling sick, having a fever, Mas."

"I've ever felt that way, Mas, it's hard to breathe in the morning, Mas, when I just woke up, Mas." 
"Oh, I had that experience, Mas, it's painful in the chest, Mas, but for shortness of breath, I have this only sometimes."

"Yes, Mas, I feel sick, Mas, in the morning when I've just waken up, Mas."

"Yes, I have, Mas, my chest was tight."

"But when I smoke... uh...my body...I felt like coughing, Mas, and I had phlegm."

Losing weight when participants smoke.

"I've got skinny when I keep smoking, Mas, I don't feel sick, Mas."

Did not experience health problems.

"Wah, I've never experienced sickness, Mas."

\section{Addiction.}

"What can I do, Mas, I'm addicted, Mas."

"Yeah, what else can I do, Mas, I feel good when smoking, this makes me keep smoking, Mas."

"I can't stand, Mas, it becomes a habit, after eating, I have to smoke, Mas, I think I've already addicted, Mas."

Feeling calm.

"When I smoke, I feel calm, Mas."

\section{Participants' Knowledge and Efforts in Re- lation to Smoking Cessation Programs}

Numerous participants did not know about smoking cessation programs, which can be seen from the interviews below:

"I've ever heard that, Mas, only heard, Mas."

"Wah, what is that, Mas, I don't know."

"Wah, I have never heard of it, Mas"

"Wah, I have never heard of this at all."

"No, Mas, I've never heard of it, Mas."

"What is that, Mas, I've never heard of it, Mas."

"I have never heard of this program, Mas."

"What is that, Mas? I don't know what that is."

"Wah, I don't know, Mas, how it looks like, Mas?

It's been a while that I want to quit smoking, but I can't."

From the interview above, it can be concluded that most participants did not know about smoking cessation programs. Although the participants did not know about the smoking cessations programs that have been officially promoted by the government, they had previously tried to quit smoking.

Although most participants started to smoke since they were young, they had tried to quit smoking at the early stage. They had tried to quit smoking for some time; that is, when they were in the junior high school, or senior high school or at college.

"Yeah, Mas, I quitted when I was in the elementary school but started to smoke again in the first grade of junior high school, in the second grade I tried to quit smoking, Mas."

"I have, Mas, I have tried to quit smoking, Mas"

"Twice, Mas, it's been a long time, Mas, two years ago when I was in the junior high school, Mas."

"In the third grade of junior high school, Mas, I'd tried to quit, Mas."

"Twice, Mas, I tried to quit smoking, Mas." "Long time ago, Mas, when I was in the junior high school and the second grade of senior high school, I tried to quit smoking, Mas."

"Twice, Mas, in the past when I was about to go to university and in the middle of college year, Mas, because of illness that I mentioned before, Mas."

"Because in the junior high school, I had a girlfriend who didn't like people who smoke."

"Yap, Mas, in the junior and senior high school, I lived alone, Mas, my parents did not monitor me, Mas."

"When I was in the senior high school, I'd tried to quit smoking, Mas, because of shortness of breath, because of illness, Mas. At that time, I changed to Marlboro cigarette, the red Marlboro."

However, their attempts to quit smoking often failed. Most participants quit smoking only for several months.

"Quit only for three months, Mas, if I'm not wrong, but then I couldn't stand, Mas."

"Oh, no, Mas, I instantly quitted, Mas, yes, I quitted, but only for several months, then I began to smoke again, Mas."

"I had, Mas, but it didn't last long, after a week, I smoked again, Mas."

"Only for a month, Mas, then I started to smoke again, Mas."

"For about a month or two, Mas, but then I couldn't stand it any longer, Mas."

"Not that long, Mas, only for 2 weeks, I quitted smoking, Mas."

"I had, Mas, for about 3 months, I quitted smoking, Mas."

The reasons participants quitting smoking were:

Financial reasons. Participants felt burdened by the cost of cigarettes bought regularly.

"Because I didn't have pocket money, Mas, that's why I quitted smoking, Mas."

Internal factors (self). Participants tried to search for other activities as a way to distract their attentions from a desire to smoke. To distract their 
attentions away from smoking, they ate food, for example, or did activities.

"Nah, in the past, when I was in the elementary school, I couldn't smoke at home because my parents were around, but during junior high school, I lived in Malang, I met friends, Mas, and started to smoke again."

"I usually eat a lot, have snacks more than usual, keep my mouth busy, Mas."

"Yeah, if I have to quit, I just quit, Mas, but I will eat lots of snacks, Mas."

"Yes, Mas, it's a matter of changing behavior, Mas, watching other people playing futsal, if they can play for a long time, why I can't play futsal that long."

"Yes, it's a matter of self-motivation, Mas, I join sports with friends that don't smoke, I feel better, Mas, I can play sports for longer time, Mas."

However, there were participants who tried to quit smoking either immediately or gradually, or they avoided environment that supported their desire to smoke.

"Yes what can I do, Mas, I just quit, quitting smoking."

"Yes, I immediately quitted, Mas, I changed the pattern of my behavior, I didn't smoke anymore, Mas."

"Yes, I can't do anything, Mas, I tried to take it, not smoking, Mas, I just held it, Mas."

"How to quit, I think, don't buy any cigarette and don't ask for a cigarette, Mas."

"Yes, the only way is not going anywhere, Mas, you just quit, Mas."

"Yap, I cut it step by step, Mas, for example, 610 cigarettes, then the next day I'd smoke only five cigarettes, Mas."

The impacts experienced by participants when they tried to quit smoking were as follows:

\section{Discomfort in mouth.}

"It doesn't feel good, Mas, craving, Mas, I want to have a cigarette in my mouth, Mas."

\section{Dizziness.}

"It's weird, Mas, if I don't smoke, I feel dizzy, Mas." Gaining weight.

"No, Mas, it's not because of illness. But when I quitted smoking, I gained weight, Mas."

Improvement in the respiratory system.

"There's a change, Mas, breathing is much easier, Mas."

\section{Saving money.}

"In terms of money, I can save money, Mas."

"In fact, I've got lots of benefits for not smoking, Mas, living a long life, living healthy, from financial perspective, I receive benefits as well, I can save money, Mas."

"I'd ever quit smoking for three months, Mas, I could save up to 250-300 thousand, Mas."

\section{Factors Influencing Participants to Quit Smoking}

\section{Participants understood the risks of smoking to health.}

"Yes, I know the risks of getting ill, Mas."

"Yap, it's hard to breathe, Mas, but when there's no breathing difficulties, I started to smoke, Mas."

"Yes, I'm a bit concerned about this pain, Mas, it's hard to breathe, Mas."

"Yeah, this is because of motivation that I have mentioned, Mas, watching friends who don't smoke, Mas, they're healthy, they can play sport for a long time, not coughing, Mas."

"Yes, my body is continuously painful, I can't play sport for long time, Mas."

"Yap, because I have difficulty to breathe, Mas, I feel my body is heavy, I have shortness of breath when doing heavy work activities."

Financial problems. Participants did not have money to purchase cigarettes.

"Because I didn't have pocket money, Mas, that's why I didn't smoke, Mas."

"Because of this, Mas, financial problems, no money."

"Yeah, what can I do, Mas, I had lots of expenses and it's not good for your health, Mas."

"Yap, because of financial problems, Mas, and I know the consequences, Mas."

\section{Society's views.}

"Why is that, Mas, because women should not smoke, Mas, people will say something bad to women who smoke, that's why I quit smoking."

"What can I say, Mas, my parents caught me when I was in the junior high school, that's why I wanted to quit, Mas."

"Yeah, I started to smoke again, Mas, what can I do, Mas, smoking is a part of my life, Mas."

\section{Discussion}

\section{Initial Factors Influencing Participants to Smoke}

Factors that initially influence people to smoke can arise from social environment and from self. Previous studies explained numerous factors that influence participants to start smoking. The main fac- 
tors were social and environmental factors that contribute to an individual's adjustment (Lloyd-Richardson, Papandonatos, Kazura, Stanton, \& Niaura, 2002; Kim, Fleming, \& Catalano, 2009).

Factors that influence adolescents to smoke have been discussed by Khurshid and Ansari (2012) and this is related to a psychosocial crisis experienced by adolescents during their development, particularly when adolescents search for their identity. Participants in the study had previously tried to quit smoking for a period of time; that is, since they were in junior or senior high school or at college, but they did not succeed.

\section{Participants' Knowledge About the Impact of Smoking}

Participants understood the risks of smoking, which can be seen from the interview excerpts. A half of participants indicated that smoking might cause painful chest and discomfort in the body as well as shortness of breath. Coughing that commonly occurs in smokers is an attempt to release thick mucus that is difficult to be removed from the airway (Hutapea, 2013). Smoking a cigarette containing a high or low level of nicotine can increase a diastolic and systolic blood pressure, increase a heart rate, and leave a demand for oxygen in heart muscles. The increased blood pressure causes norepinephrine to be released locally from axon terminals that are adrenergic and leaves a demand for oxygen in heart muscles causing the release of catecholamine from the adrenal medulla and chromaffin tissue in the heart. Nicotine works on chemoreceptors in the carotid and aortic bodies that cause increased pulse rate and arterial pressure, and therefore, the low levels of nicotine can stimulate hyaline cells of the sympathetic ganglion (Hutapea, 2013).

Most participants knew the health risks of smoking, in particular the risk of having lung cancer. This is possibly because of the educational backgrounds of participants where most of them had completed studying or still studied at the faculty of pharmacy which is a health-related field of study. Although the majority of participants had academic qualifications in the health area, they might not have an awareness of the benefits of quitting smoking. The most important factor that influences smokers to quit smoking is their own awareness and social support from their family (Ardini \& Hendriani, 2012).

\section{Participants' Knowledge and Efforts In Re- lation to Smoking Cessation Programs}

Almost all participants explained that they had never heard of smoking cessation programs. There is not many people overseas who know about smoking cessation although the guidelines of smoking cessation have been developed, for example Smoking Cessation Guideline for Australian General Practice (2004, as cited in Department of Health and Ageing, 2014). The World Health Organization Regional Office for Europe (2013) developed similar guidelines in the European Tobacco Control Status Report 2013 and the European Network for Smoking and Tobacco Prevention aisbl (ENSP; 2012) has developed the European Smoking Cessation Guideline. Nonetheless, based on the 2002 data in the United States, in the last five years, 23.5\% adult smokers decided to continue smoking and $33 \%$ of them were under the age of 24 years.

Notably, the guidelines and journal articles published in Europe and Australia did not report the prevalent rates of community members who participated in smoking cessation programs, including those involved in certain programs and those showing their own initiatives. Further, there has been no data on the effectiveness of smoking cessation programs associated with the guideline. In Indonesia, in 2002 the WHO indicated that Indonesia was the top fifth country in consuming cigarettes.

Furthermore, smoking cessation programs have already been implemented to promote health levels using a cognitive therapy, a behavioral therapy and medications. This has been conducted because smoking is associated with reversible damage potential and dose-related arterial dilation of endotheliumrelated. It causes the narrowing of proximal and distal epicardial coronary arteries and increased coronary vascular tone despite the increased needs for oxygen in myocardial infarctions and smokers show a basal decrease which is not stimulated by nitric oxide induced by vasodilation (Pittilo, 2000).

Economic factors can influence smokers' decision by increasing their desire to quit smoking, as experienced by several participants. This mainly occurs among smokers with low socioeconomic status. Hence, smokers generally prefer to stop a treatment (for diseases/problems due to smoking or others) rather than to quit smoking because of economic reasons. In this case, the government's policy raising the price of tobacco products is basically an 
intervention to control tobacco that seems to be the most potential way to reduce the health risks of consuming tobacco (Hiscock, Bauld, Amos, Fidler, \& Munafo, 2012: Hiscock, Judge, \& Bauld, 2011).

There were smokers in this study who quitted their habit of smoking independently or without following a therapy. Individuals are considered to be independent if they attempt to quit smoking because they have a desire to become themselves, can make a decision based on their own consideration, and are responsible for their own decisions. Many participants quit smoking only by hanging their behavior on the basis of their own desires and without taking medications (Ardini \& Hendriani, 2012). Few examples of attempts to quit smoking that are related to internal factors (self) are searching for activities to distract their attention from smoking, such as playing sport or doing exercises and others (Ardini \& Hendriani, 2012).

Smoking dependence can be defined as a pleasure that generates a psychological satisfaction. The symptom is called tobacco dependence, that is, smoking behavior which is pleasurable and can shift into obsessive activities. According to Kassel, Stroud, and Paronis (2003), the motives of smoking are relaxation to reduce tensions, improve concentration, and create enjoyable experiences and relaxation. Efforts made to quit smoking were avoiding the environment that increased smoking desires and reducing gradually the frequency of smoking.

\section{The Consequences Experienced by Partici- pants When Trying to Quit Smoking were:}

Discomfort in mouth. Smoking habit potentially decreases the sensitivity of taste. The negative effect of smoking on the soft tissues of teeth and mouth varies depending on age, gender, lifestyle, types of cigarettes, duration of smoking, and daily consumption of cigarettes (Dewi, 2005). The sensitivity to bitter taste occurs more frequently in smoker groups. Taste receptors on the entire surface of tongue can recognize sweet and bitter taste, but taste receptors in certain locations are more sensitive than others (Simamora \& Primasari, 2012). Smokers who have recently quit smoking may experience discomfort in mouth, such as coughs, dry throat and mouth. This may be due to nose and throat attempts to remove mucus that is produced from the previous smoking (Sadikin \& Louisa, 2011).
Dizziness and restlessness. Nicotine in cigarettes causes an addiction (dependence). When a person quits smoking, the body's need for nicotine is not met, the receptors previously bounded with nicotine are no longer connected, and this will cause the symptoms of nicotine withdrawal that generally occurs 1-2 days after quitting smoking, such as dizziness/headache, weaknesses, nausea, anxiety, desires to smoke, concentration difficulties, sleeplessness, mood changes; that is, becoming more sensitive and easily angry, excessive hunger, and so forth (ASH Fact Sheet on Smoking and Cancer, 2013).

Gaining weight. Smoking influences the appetite, specifically nicotine can cause a decrease in appetite. Nicotine in cigarettes has an effect on a decrease in appetite, when a person smokes, nicotine derived from tobacco will be absorbed quickly into the lung and absorbed into the veins in the lung, and then enters the brain that will bind it to the nicotinic receptors connected to the ion channel (Grillner \& Svensson, 2000), which open to the incoming cations, such as sodium and potassium and release a variety of neurotransmitters. This process will lead to the release of catecholamine, dopamine, serotonin, norepinephrine, GABA (Gamma Aminobutyric Acid) and other neurotransmitters (McGovern \& Benowitz, 2011), in order that the central nervous system releases several neurotransmitters associated with a decrease in appetite (Carr, Kim, \& Vaca, 2000). The higher the levels of nicotine in blood, the stronger their stimulation to postsynaptic cells in nicotinic receptors (Zhou, Gao, \& Picciotto, 2015).

Improving in respiratory health system, breathing more easily. Smoking increases the risk of lung disease, thus, quitting smoking will improve the function of lung. Smoking can lead to lung diseases in the long term, such as emphysema and chronic bronchitis, or commonly known as chronic obstructive pulmonary disease (COPD), with the main symptoms of shortness of breath. COPD causes chronic illness and disability that deteriorate over time and sometimes, can be fatal (ASH Fact Sheet on Smoking and Cancer, 2013).

Improving in economic factor. The most noticeable advantage after participants stopped smoking for a period of time is the cost (economic factor) and health factor. Addiction due to nicotine dependence causes a smoker to purchase cigarettes regularly because nicotine in cigarettes has gradually changed his or her brain cells that make the smoker 
feel the urge to smoke.

\section{Factors Influencing Participants to Quit Smoking}

Health factors. Participants knew the health risks of smoking and therefore, they had a desire to quit smoking. The brain reacts to the incoming nicotine by sending a signal to the adrenal glands in order to release epinephrine (adrenaline). This powerful hormone will react by constricting blood vessels, and because of the narrowing brain blood vessels, the heart will work harder due to the higher pressure. If the pumping of the heart is sufficiently strong and blood vessels in the brain are constricted due to the strong reaction to epinephrine, then the blood vessels of the brain will be broken and this causes a stroke.

Current smokers have at least a two to fourfold increase in the risk of stroke compared to never smokers or individuals who has quitted smoking for more than 10 years (Shah, \& Cole, 2010). In addition, cigarette smoke can also trigger respiratory problems, such as the occurrence of symptoms of breathing problems, declined lung function, and asthma attacks (Hutapea, 2013).

Financial factors. Participants did not have sufficient money to purchase cigarettes.

Social factors. Participants may quit smoking because of social factors, such as a judgement that women should not smoke. Female smokers compared to male smokers are perceived negatively in society. A negative stigma to female smokers influences the meaning of smoking to female adolescent smokers. The process to form the meaning of smoking to female adolescent smokers is also influenced by their purpose of smoking, smoking becomes the symbol of 'cool' appearance, or the symbol of rebellion, or a way to gain pleasure (Martini, 2014).

\section{Limitations of Study}

Limitations of this study are related to the participants' backgrounds, which are explained as follows:

Gender. This study involved participants from both gender (males and females). However, previous studies have indicated that gender is related to people's attitude to smoking, due to negative stigma and a greater pressure from the society on female smokers compared with male smokers. This has caused female smokers' desire to quit smoking is greater than male smokers because of pressure from the society.

Place of origin. All participants in this study had their education in Surabaya, however, we did not consider participants' place of origin. Differences in the place of origin might influence participants' perception and attitudes towards smoking. People living in rural areas had a higher frequency of smoking in comparison to people living in urban areas (GATS, 2012).

Age. Age of participants in this study was at the range of young adults who was still undergraduate students, excluding those with older age. Thus, the results of this study can only be generalized to students of similar age to the participants in this study. Older-aged students was excluded because the Latin American Project for Investigation of Obstructive Lung Disease (PLATINO) reported that the prevalence of COPD was higher in smoker and ex-smoker groups than never-smoke groups, as well as in people aged over 40 than below 40 . The prevalence of COPD was also higher in males than females (GOLD, 2014).

\section{Conclusions}

Participants' smoking initiation was influenced by their own curiosity and environment, such as family or friends. All participants understood the risks and consequences of smoking, and had previously tried to quit smoking since smoking influenced their life, causing financial and health problems. Notably, although they had received the benefits of quitting smoking, such as improvements in respiratory health, cost savings, and freshness due to quitting smoking, participants failed to stop smoking. This failure might be caused by a discomfort arising from not smoking as a result of addiction to nicotine in cigarettes. This study only described the initial conditions of active smokers and their problems when they tried to quit smoking. Therefore, further study should follow this up with a solution in terms of designing and developing the most effective smoking cessation programs.

Smoking cessation programs should not only increase smokers' knowledge, but should also change their attitudes and perception. It is expected that smoking cessation programs will not only focus on increasing the knowledge about the risks of smoking, but also actively overcoming the challenges faced by smokers when they try to quit smoking.

\section{References}

Ardini, R. F., \& Hendriani, W. (2012). Proses berhenti merokok secara mandiri pada mantan pe- 
candu rokok dalam usia dewasa awal. Jurnal Psikologi Pendidikan dan Perkembangan, 1(2), 1-7. ASH Fact Sheet on Smoking and Cancer. (2013). Smoking and cancer: Action on smoking and health [online]. Retrieved from http://www.ash.or g.uk/files/documents/ASH_109.pdf

Berrenderoa, F., Robledoa, P., Trigoa, J. M., MartínGarcíaa, E., \& Maldonadoa, R. (2010). Neurobiological mechanisms involved in nicotine dependence and reward: Participation of the endogenous opioid system. Neuroscience and Biobehavioral Reviews, 35, 220-231.

BPOM (Badan Pengawas Obat dan Makanan Republik Indonesia) (2005). Upaya Tobacco Control (TC). InfoPOM, 8(4), 1-6.

BPOM (Badan Pengawas Obat dan Makanan Republik Indonesia). (2007). Bangkitkan kesadaran remaja terhadap bahaya merokok. InfoPOM, 8(4), $1-3$.

Carr, K. D., Kim, G., \& Vaca S. (2000). Hypoinsulinemia may mediate the lowering of self-stimulation thresholds by food restriction and streptozotocin-induced diabetes. Brain Research, 863(12), 160-168.

Department of Health and Ageing (2014). Smoking cessation guideline for Australian general practice handbook 2004 edition [online]. Retrieved from http://apps.who.int/fctc/reporting/Australia_ annex8_smoking_cessat ion_guidelines.pdf

Dewi, D. (2005). Pengaruh kebiasaan merokok terhadap mukosa mulut. Dentika Dental Journal, 10(2), 132-135.

European Network for Smoking and Tobacco Prevention (ENSP) (2012). European Smoking Cessation Guidelines: The authoritative guide to a comprehensive understanding of the implications and implementation of treatments and strategies to treat tobacco dependence. Revised 1st edition [online]. Retrived from http://www.toraks.org.tr/ userfiles/file/ENSP-ESCG_FINAL.pdf.

Fawzani, N., \& Triratnawati, A. (2005). Terapi berhenti merokok (studi kasus 3 perokok berat). $M a-$ kara Kesehatan, 9(1), 15-22.

GATS. (2012). Global Adult Tobacco Survey: Fact sheet Indonesia report 2011. National Institute of Health Research and Development and World Health Organization (pp.1-2).

GOLD (Global Obstructive Lung Disease). (2014). Global initative for chronic obstructive lung disease (Update).

Grillner, P., \& Svensson, T. H. (2000). Nicotine-induced excitation of mid-brain dopamine neurons in vitro involves ionotropic glutamate receptor activation. Synapse, 38, 1-9.

Guillon, M. S., Crocq, M. A., \& Bailey, P. E. (2007). Nicotine dependence and self-esteem in adolescents with mental disorders. Addictive Behaviours, 32(4), 758-764.

Health United States, (2010). Health United States 2010 with special features and dying. U.S. Government Printing Office (pp. 28-35).

Hiscock, R., Judge, K., \& Bauld. (2011). Social inequalities in quitting smoking: what factors mediate the relationship between socioeconomic position and smoking cessation? Journal of Public Health, 33(1), 39-47.

Hiscock, R., Bauld, L., Amos, A., Fidler, J. A., \& Munafo, M. (2012). Socioeconomic status and smoking: A review. Annals of the New York Academy of Sciences, 1248, 107-123. DOI: $10.1111 / \mathrm{j}$.

Hutapea, R. (2013). Why rokok? Tembakau dan peradaban manusia. Jakarta, Indonesia: PT Bee Media Indonesia.

Kassel, J. D., Stroud, L. R., \& Paronis, C. A. (2003). Smoking, stress, and negative affect: Correlation, causation, and context across stages of smoking. Psychological Bulletin, 129(2), 270-304.

Khurshid, F., \& Ansari, U. (2012). Causes of smoking habit among the teenager. Interdisciplinary Journal of Contemporary Research in Business, 3(9), 848-855.

Kim, M. K., Fleming, C. B., \& Catalano, R. F. (2009). Individual and social influences on progression to daily smoking during adolescence. Pediatrics, 124(3), 895-902.

Lloyd-Richardson, E. E., Papandonatos, G., Kazura, A., Stanton, C., \& Niaura, R. (2002). Differentiating stages of smoking intensity among adolescents: Stage-specific psychological and social influences. Journal of Consulting and Clinical Psychology, 70(4), 998-1009.

Mansvelder, H. D., \& McGeHee, D. S. (2002). Cellular and synaptic mechanisms of nicotine addiction. Journal of Neurobiology, 53, 606-617.

Martini, S. (2014). Makna merokok pada remaja putri perokok (Smoking meaning in young women smokers). Jurnal Psikologi Pendidikan dan Perkembangan, 3(2), 119 - 127.

McGovern, J. A., \& Benowitz, N. L. (2011). Cigarette smoking, nicotine, and body weight. Clinical Pharmacology \& Therapeutics, 90(1), 164-168.

Neal, L., \& Benowitz, M. D. (2008). Neurobiology of nicotine addiction: Implications for smoking 
cessation treatment. The American Journal of Medicine, 121(4A), S3-S10.

PP No. 81 tahun 1999 (Peraturan Pemerintah Republik Indonesia Nomor 81 Tahun 1999, tentang pengamanan rokok bagi kesehatan. (2000). Jakarta: Lembaran Negara Republik Indonesia.

Pittilo, R. M. (2000). Cigarette smoking, endothelial injury and cardiovascular disease. International Journal of Experimental Pathology, 81(4), 219-230.

Sadikin, Z. D., \& Lousia, M. (2011). Program berhenti merokok. Majalah Kedokteran Indonesia, 58(4), 130-137.

Shah, S., \& Cole, W. (2010). Smoking and stroke: The more you smoke the more you stroke, NIH: Public Access, 917-932.

Sinclair, H. K., Bond, C. M., \& Stead, L. F. (2008). Community pharmacy personnel interventions for smoking cessation (Review). Cochrane Database of Systematic Reviews, 4, CD003698.

Simamora, \& Primasari, A. (2012). Change of taste sensitivity of clove cigarette smokers in Medan marlina. Journal of Dentistry Indonesia, 19(2), 27-31.
Twyman, L., Bonevski, B., Paul, C., \& Bryant, J. (2014). Perceived barriers to smoking cessation in selected vulnerable groups: A systematic review of the qualitative and quantitative literature. BMJ Open, 4(12), e00641.

Veny, M. B., Beltrán, J. P., Torrente, S. G., González, P. S., Pons, A. A., Riera, P. T. (2011). Self-perceived factors associated with smoking cessation among primary health care nurses: A qualitative study. Revista Latino-Americana de Enfermagem, 19(6), 1437-1444.

World Health Organization Regional Office for Europe. (2013). European tobacco control status report 2013 [online]. Retrived from http://www .euro.who.int/_data/assets/pdf_file/0011/235973 /European-Tobacco-Control-Status-Report-2013Eng.pdf

Zhou, W. L., Gao, X. B., \& Picciotto, M. R. (2015). Acetylcholine acts through nicotinic receptors to enhance the firing rate of a subset of hypocretin neurons in the mouse hypothalamus through distinct presynaptic and postsynaptic mechanisms. eNeuro, 2(1), 0052-14.2015. 